\title{
Effect of temperature on the crack growth in pipe steel X70 in a weakly acidic electrolyte
}

\author{
A.I. Marshakov, ${ }^{1}$ Vo Tien, ${ }^{2}$ V.E. Ignatenko ${ }^{1}$ and A.V. Muradov ${ }^{2}$ \\ ${ }^{1}$ A.N. Frumkin Institute of Physical Chemistry and Electrochemistry, Russian Academy \\ of Sciences, Leninsky pr. 31, Moscow, 119071 Russian Federation \\ ${ }^{2}$ Gubkin Russian State University of Oil and Gas, Leninsky pr. 65, Moscow, \\ 119991 Russian Federation \\ E-mail: mar@ipc.rssi.ru
}

\begin{abstract}
The temperature dependences of crack growth in static tests of X70 pipe steel in citrate buffer ( $\mathrm{pH}$ 5.5) and in the same solution containing $1 \mathrm{mM}$ sulfide were studied. The activation energies of corrosion crack growth were determined. It was shown that addition of IFKhAN-29-3 organic corrosion inhibitor hindered the crack growth and the protective effect increased with an increase in temperature.
\end{abstract}

Key words: pipe steel, stress corrosion cracking, weakly acidic buffer, inhibitor, temperature, activation energy.

Received: March 02, 2017. Published: April 04, 2017.

doi: $\underline{10.17675 / 2305-6894-2017-6-2-5}$

\section{Introduction}

Stress corrosion cracking (SCC) of low-alloyed pipe steels is the most hazardous type of corrosion of buried high-pressure pipelines [1-6]. To date, it has been established rather reliably that the pattern of SCC of pipe steels under pipeline operation conditions is mainly determined by the composition of the soil electrolyte. In sufficiently concentrated carbonate electrolytes with $\mathrm{pH}$ above 9, the "classical" intergranular SCC is observed, which occurs in a narrow range of potentials around the active-passive transition. In dilute electrolytes with near-neutral $\mathrm{pH}(5-7.5)$, transgranular cracking of pipe steel occurs in the potential region of its active dissolution. These two SCC types differ considerably from each other in how the chemical composition of the corrosive environment, electrode potential, and mode of mechanical stress affect the corrosion crack growth. The temperature is also a factor that differently affects the crack growth in alkaline and neutral electrolytes.

The regularities of the $1^{\text {st }}$ type $\mathrm{SCC}$ (at high $\mathrm{pH}$ ) was studied in the temperature range from $20^{\circ} \mathrm{C}$ to $90^{\circ} \mathrm{C}$, where the crack growth rate increased exponentially with an increase in the temperature $[2,5-7]$. The crack growth rate depended both on the potential and on the temperature and varied in the range of $c a \cdot 10^{-7}$ to $10^{-6} \mathrm{~mm} / \mathrm{s}$. The potential range corresponding to SCC shifted towards the negative region with an increase in the 
temperature and depended on the composition of the carbonate-bicarbonate solution [8]. The crack growth activation energy $\left(E_{\mathrm{a}}\right)$ also varied depending on the electrolyte composition: in was 20.2 or $20 \mathrm{~kJ} / \mathrm{mol}$ in $1 \mathrm{M} \mathrm{NaHCO}_{3}$ solution saturated with $\mathrm{CO}_{2}$ and without it, respectively; $42.3 \mathrm{~kJ} / \mathrm{mol}$ in the $0.125 \mathrm{M} \mathrm{NaHCO}_{3}+0.062 \mathrm{M} \mathrm{Na}_{2} \mathrm{CO}_{3}$ solution; and $34.8 \mathrm{~kJ} / \mathrm{mol}$ in $1 \mathrm{M} \mathrm{NaHCO}_{3}+0.75 \mathrm{M} \mathrm{Na}_{2} \mathrm{CO}_{3}$ solution. It should be noted that the crack growth rate was determined in slow strain rate tests (the SSRT method) [8], so the $E_{\mathrm{a}}$ value could correspond both to the corrosion defect (stress point) nucleation process and to the corrosion crack growth process. However, experiments carried out in $1 \mathrm{M} \mathrm{NaHCO}_{3}+$ $0.5 \mathrm{M} \mathrm{Na} \mathrm{NaO}_{3}$ solution on steel samples with a pre-grown fatigue crack gave approximately the same value of $E_{\mathrm{a}}=41.8 \mathrm{~kJ} / \mathrm{mol}$. Hence, the $E_{\mathrm{a}}$ values that we obtained mostly belong to the crack growth process.

The temperatures of the pipe and the soil near the pipe depend on the distance from the compressor station and may range from $40^{\circ} \mathrm{C}$ at the pipeline exit from the station, down to negative values. Based on the plots of the crack growth in carbonate-bicarbonate solutions $v s$. temperature, the preferential appearance of type 1 SCC defects near compressor stations was explained [3-7]. Transgranular cracks, i.e., the $\mathrm{pH}$-neutral SCC (or type $2 \mathrm{SCC}$ ), were observed at considerable distances (up to $67 \mathrm{~km}$ ) from the compressor station [9]. This fact provided a reason to believe that type 2 SCC did not depend on the temperature. However, it was noted subsequently that the maximum number of SCC defects was observed near compressor stations [1], which however may be due to the effects of other factors, primarily the large amplitude of changes in the mechanical stress of the pipe metal.

The resistance of X65 steel against type 2 SCC was studied by SSRT method in the temperature range from 5 to $45^{\circ} \mathrm{C}$ in the NS4 solution that simulates the composition of the "underfilm" electrolyte under a delaminated coating [9]. No effect of temperature was observed, but the data reported in [9] have a considerable scatter than may mask the temperature effect [2]. Similarly, in pure bicarbonate solutions $(0.1-1 \mathrm{~g} / 1)$ through which an inert gas containing a $\mathrm{CO}_{2}$ admixture for creating a neutral $\mathrm{pH}$ was bubbled, no noticeable variation in the crack growth rate in the temperature range from 15 to $35^{\circ} \mathrm{C}$ was noticed [10]. An insignificant increase in the crack growth rate (from $7 \cdot 10^{-6}$ to $9 \cdot 10^{-6}$ $\mathrm{mm} / \mathrm{s}$ ) was observed upon an increase in the temperature from 35 to $60^{\circ} \mathrm{C}$, but this difference cannot be considered statistically significant [11]. Thus, the lack of a temperature dependence is believed to be one of the indicators of transgranular $\mathrm{pH}$-neutral SCC, though the reasons of the independence of crack growth on the temperature are unknown.

SSRT tests of pipe steels X60 and X65 in the standard NACE solution saturated with hydrogen sulfide have shown an insignificant, but still clearly observable, increase in the sensitivity of the material to transgranular SCC with an increase in the temperature from 25 to $50^{\circ} \mathrm{C}$ [12]. The acidity of the NACE solution (solution B) should be in the range: $3.4<\mathrm{pH}<4$ [13]. Hence, the dependence of transgranular SCC on the temperature manifests itself more distinctly in acidic electrolytes. 
It has been reliably established to date that the SCC of pipe steels at high $\mathrm{pH}$ occurs by the mechanism of local dissolution of intercrystalline boundaries [1-7]. The mechanism of pH-neutral SCC has been understood less reliably. Many researchers believe that the growth of a transgranular crack occurs by the corrosion fatigue mechanism and is initiated by hydrogen absorbed by the metal [5-7]. Moreover, the assumption on the synergistic effect of local metal dissolution and hydrogen absorption was often made [1]. It has been shown that the nature of the predominant mechanism of $\mathrm{pH}$-neutral SCC of pipe steel X70 depends on the cyclic mechanical strain mode and on the electrode potential [14-17]. In fact, local dissolution of the metal is the predominant mechanism of SCC at relatively small amplitudes of cyclic strain variation and at the steel corrosion potentials in NS4 solution ( $\mathrm{pH}$ 6.8). Hydrogen embrittlement of the metal may become the predominant mechanism of pipe steel SCC upon a considerable negative shift of potential and under "drastic" mechanical strain, e.g., in SSRT tests [18]. In a weakly acidic buffer electrolyte with $\mathrm{pH}=5.5$ (i.e., at the threshold of the solution acidity corresponding to type II SCC), the crack growth occurs not only under cyclic strain by also under constant tensile stress. It was established that local metal dissolution is the predominant mechanism of transgranular crack growth [14-18]. Apparently, SCC in a weakly acidic buffer electrolyte is a special case of transgranular SCC of pipe steels and may demonstrate a number of specific features.

The main purpose of this research is to study the effect of the temperature on the crack growth rate in pipe steel X70 in a weakly acidic buffer solution ( $\mathrm{pH}$ 5.5). Yet another purpose is to check the applicability of organic inhibitors such as IFKhAN-29 [19] for hindering the SCC of pipe steel at various temperatures.

\section{Experimental}

The crack growth rate was determined on samples made of X70 strength grade steel, cut from a pipe manufactured at Khartsyzsk tube plant $(1420 \times 18.7 \mathrm{~mm})$. The chemical composition and strength parameters of the steel are reported elsewhere [15-17].

Samples with dimensions of $200 \times 17 \times 3 \mathrm{~mm}$ were cut from a pipe along the axial line, at a distance of $120 \mathrm{~mm}$ from the longitudinal weld. Before the experiments, triangular stress concentrators $3 \mathrm{~mm}$ deep were cut in the samples. After that, fatigue cracks $c a .5 \mathrm{~mm}$ deep were grown in the specimens to serve as crack growth initiators in the corrosion experiments. Specimens with cracks were fastened in three-electrode electrochemical cells that were then filled with the electrolyte being studied.

A static tensile mechanical load was applied to the specimens. The stress intensity factor at the crack tip $K\left(\mathrm{MPa} \cdot \mathrm{m}^{0.5}\right)$ was carried out according to [15-17]. The initial value, $K=45 \mathrm{MPa} \cdot \mathrm{m}^{0.5}$, was chosen on the plateau of the kinetic curve of X70 steel fracture curve, i.e., under the conditions where the crack growth rate nearly does not depend on $K$ $[14,17]$. 
The crack growth rate $(V)$ was determined from the slope of the plot of electric conductivity of samples in the vicinity of the crack $\left(R_{\mathrm{t}}\right) v s$. the test time $(\tau)$ :

$$
V=l_{0}\left(R_{\mathrm{t}} / R_{0}-1\right) / \tau=\Delta l / \tau,
$$

where $R_{0}$ is the initial specimen resistance, $l_{0}$ is the initial crack length, and $\Delta l$ is the crack length gain. The $R_{\mathrm{t}}$ value was determined with correction for the change in the sample temperature during the experiment; to do so, the current electric resistance of sample sections containing a crack $(R)$ and without a crack $\left(R_{\mathrm{w} / 0 / \mathrm{c}}\right)$ and $R_{\mathrm{t}}$ was calculated as

$$
R_{\mathrm{t}}=R \cdot R_{\mathrm{w} / \mathrm{o} / \mathrm{c}} / R_{0, \mathrm{w} / \mathrm{o} / \mathrm{c}}
$$

where $R_{0, \mathrm{w} / \mathrm{o} / \mathrm{c}}$ is the initial resistance of the sample section without a crack. The resistance of the samples was measured with a BSZ-100-002 microhmmeter with an accuracy of $10^{-8} \mathrm{Ohm}$.

The tests were carried out at room temperature whose mean values during the tests were $26^{\circ} \mathrm{C}$ or $25^{\circ} \mathrm{C}$ (with the maximum temperature variations of $\pm 3^{\circ} \mathrm{C}$ ), on cooling the solution in the cell with a water hood, and on heating by means of an electric heating element. The temperatures were maintained to within $\pm 1^{\circ} \mathrm{C}$. The mean temperatures during the tests are listed in Table 1.

Table 1. Temperatures $(t)$, crack growth rates $(V)$ and activation energies of crack growth $\left(E_{\mathrm{a}}\right)$ in the media studied.

\begin{tabular}{cccc}
\hline Medium & $\boldsymbol{t}^{\circ}{ }^{\circ} \mathbf{C}$ & $\mathbf{V}, \mathbf{m m} / \mathbf{s}$ & $\boldsymbol{E}_{\mathbf{a}}, \mathbf{k J} / \mathbf{m o l}$ \\
\hline & 62 & $4.2 \cdot 10^{-7}$ & \\
$\mathrm{CB}$ & 43 & $1.9 \cdot 10^{-7}$ & 31.1 \\
& 26 & $1.2 \cdot 10^{-7}$ & \\
& 12 & $5.6 \cdot 10^{-7}$ & \\
$\mathrm{CB}+\mathrm{Na}_{2} \mathrm{~S}$ & 62 & $8.1 \cdot 10^{-7}$ & \\
& 43 & $4.2 \cdot 10^{-7}$ & 32.3 \\
& 26 & $2.2 \cdot 10^{-7}$ & \\
\hline & 12 & $1.0 \cdot 10^{-7}$ & \\
$\mathrm{CB}+\mathrm{IFKhAN}-29-3$ & 61 & $1.9 \cdot 10^{-7}$ & \\
& 25 & $5.6 \cdot 10^{-8}$ & 30.4 \\
& 11 & $2.8 \cdot 10^{-8}$ & \\
\hline & 61 & $2.8 \cdot 10^{-7}$ & \\
$\mathrm{CB}+\mathrm{Na}_{2} \mathrm{~S}+\mathrm{IFKhAN}-29-3$ & 25 & $8.3 \cdot 10^{-8}$ & 25.7 \\
& 11 & $5.8 \cdot 10^{-8}$ & \\
\hline
\end{tabular}


The following working background solutions were used:

1) citrate buffer (CB), pH $5.5\left(0.08 \mathrm{M} \mathrm{C}_{6} \mathrm{H}_{8} \mathrm{O}_{7}+0.05 \mathrm{M} \mathrm{NaOH}+0.1 \mathrm{M} \mathrm{KCl}\right)$;

2) citrate buffer ( $\mathrm{pH} 5.5)$ with addition of $1 \mathrm{mM} \mathrm{Na}_{2} \mathrm{~S}\left(\mathrm{CB}+\mathrm{Na}_{2} \mathrm{~S}\right)$.

The concentration of the IFKhAN-29-3 inhibitor [19] added to the working solutions was $1 \mathrm{~g} / \mathrm{l}$. All the solutions were prepared from reagent grade chemicals using distilled water. The experiments were carried out at the corrosion potential with free access of air.

\section{Results and discussion}

Figure 1 shows the increase in the crack length $(\Delta l)$ with time in the background electrolytes: $\mathrm{CB}$ (a) and $\mathrm{CB}+\mathrm{Na}_{2} \mathrm{~S}$ (b). The shapes of the $\Delta l-\tau$ plots in the solutions containing the inhibitor were the same as in Figure 1. The tests were started at room temperature $\left(26^{\circ} \mathrm{C}\right)$, then the solution temperature was increased and then decreased (the times of temperature change are shown by vertical dashed lines in Figure 1). Assuming that the crack growth rate does not change with time at constant temperature, the $V$ values were calculated by Eq. (1) from the slopes of the corresponding linear parts on the $\Delta l-\tau$ curve. The $V$ values at $26^{\circ} \mathrm{C}$ determined before and after the measurements at elevated temperatures were either equal, or the initial crack growth rate at room temperature was lower (Figure 1). The reasons of the latter effect were not studied. However, to eliminate its possible effect, we compared only the $V$ values determined upon a gradual decrease in the solution temperature (Table 1).

Figure 2 shows the effect of the solution temperature on the crack growth rate. One can see that the maximum $V$ variation $v s$. temperature is observed in the background citrate solution containing sodium sulfide. Addition of the inhibitor hinders the crack growth considerably and the dependence of $V$ on temperature becomes weaker. It should be noted that the scatter of $V$ values determined under equivalent external conditions is generally rather considerable; this is apparently due to the inhomogeneity of the material structure. For example, the range of $V$ values obtained in this study and in $[15,19]$ in CB solution at the corrosion potential at room temperature $\left(22-26^{\circ} \mathrm{C}\right)$ is shown by the dashed rectangle in Figure 2. These values differ approximately by a factor of 2 , but one can see that the change in the crack growth rate with temperature considerably exceeds the specified data scatter (Figure 2).

The change in $V v s$. temperature in all the media studied obeys the Arrhenius relationship:

$$
V=A \exp \left(-E_{\mathrm{a}} / R T\right) .
$$

In order to exclude the pre-exponent coefficient $A$, let us convert Eq. (3) to the form:

$$
\ln \left(V / V_{\text {ref }}\right)=-E_{\mathrm{a}} / R\left(1 / T-1 / T_{\text {ref }}\right),
$$

where $V_{\text {ref }}$ is the crack growth rate at temperature $T_{\text {ref, }}$ which was chosen for comparison with other $V$ values. We chose the crack growth rates at the maximum temperatures studied 
as $V_{\text {ref }}\left(T_{\text {ref }}=335 \mathrm{~K}\right.$ in the background electrolytes; $T_{\text {ref }}=334 \mathrm{~K}$ in the inhibited media), since the higher the $V$ value, the more accurately it can be determined within an experiment of certain duration. Figure 3 shows the $V$ plots $v s$. temperature obtained in the solutions studied, in the coordinates corresponding to Eq. (4). As one can see, these relationships are linear and the correlation coefficients are close to 1 . The activation energies calculated from the data in Figure 3 are shown in Table 1.
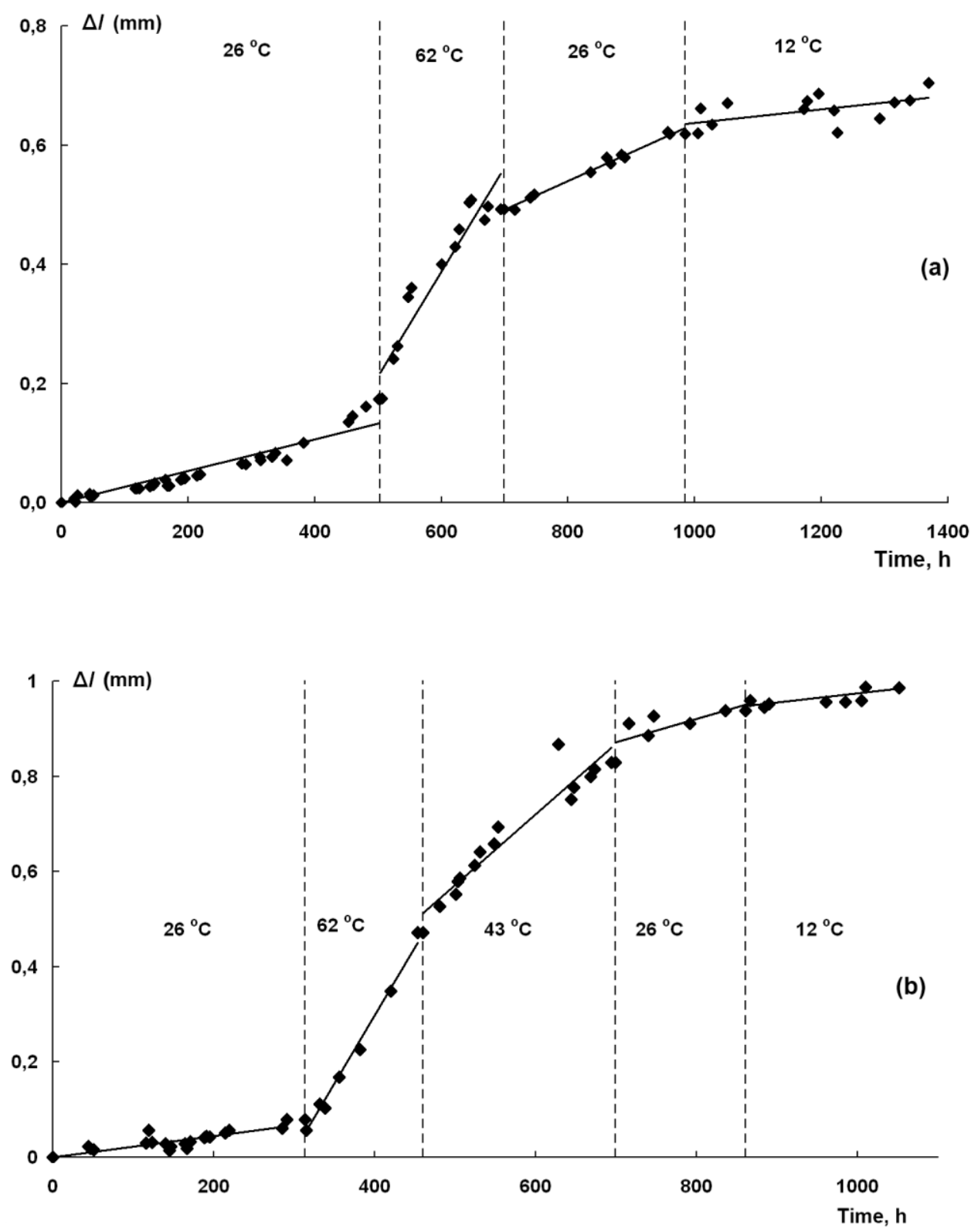

Figure 1. The increase in the crack length with time at various temperatures (shown in the Figure) in solutions: $\mathrm{CB}(\mathrm{a}), \mathrm{CB}+\mathrm{Na}_{2} \mathrm{~S}(\mathrm{~b})$. 


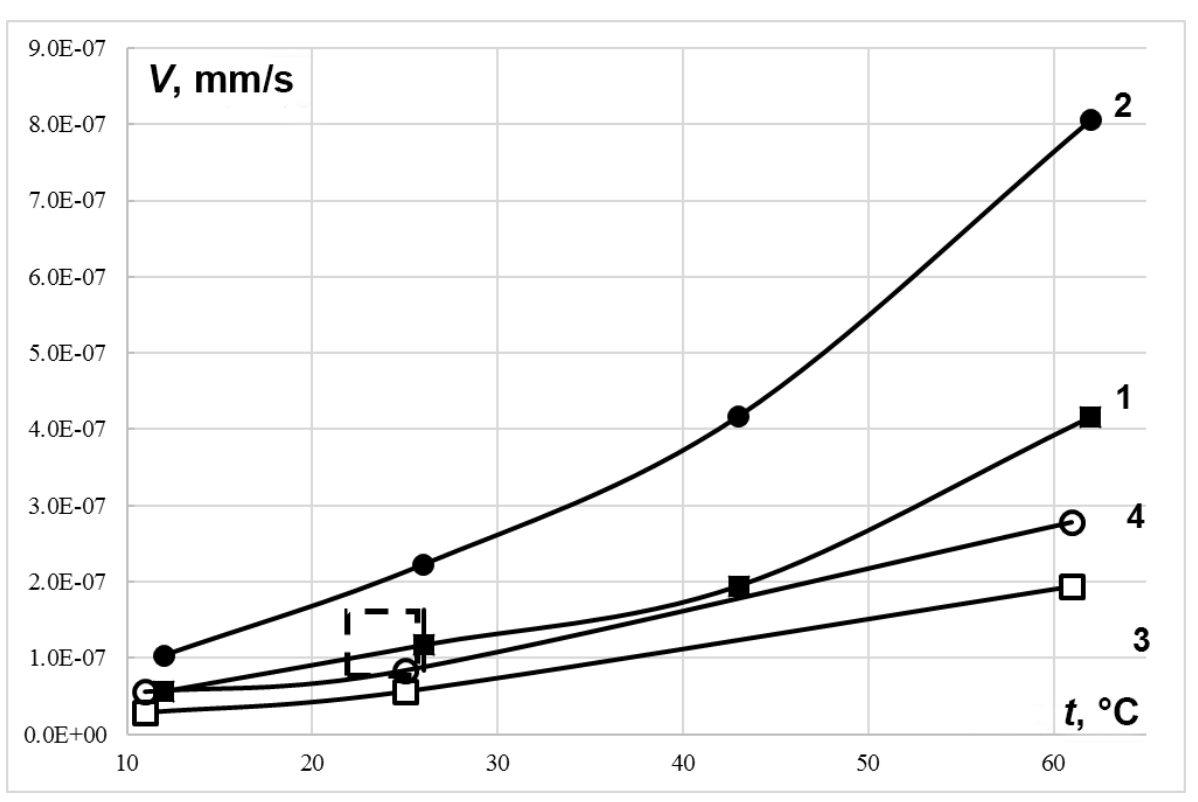

Figure 2. The change in the crack growth rate vs. temperature in solutions: $\mathrm{CB}(1), \mathrm{CB}+\mathrm{Na}_{2} \mathrm{~S}$ (2), $\mathrm{CB}+\mathrm{IFKhAN-29-3} \mathrm{(3),} \mathrm{and} \mathrm{CB}+\mathrm{Na}_{2} \mathrm{~S}+$ IFKhAN-29-3 (4).

As one can see, curves 1 and 2 (Figure 3 ) obtained in the background $\mathrm{CB}$ and $\mathrm{CB}+\mathrm{Na}_{2} \mathrm{~S}$ solutions nearly coincide and the corresponding $E_{\mathrm{a}}$ values, 31.1 and $32.3 \mathrm{~kJ} / \mathrm{mol}$, are similar. These values are in the range of $E_{\mathrm{a}}=20-42.3 \mathrm{~kJ} / \mathrm{mol}$ that was determined for the transgranular SCC of pipe steels in carbonate-bicarbonate electrolytes (see above). The activation energy of anodic dissolution of pipe steel in these solutions is assumed to be $42 \mathrm{~kJ} / \mathrm{mol}[20]$.

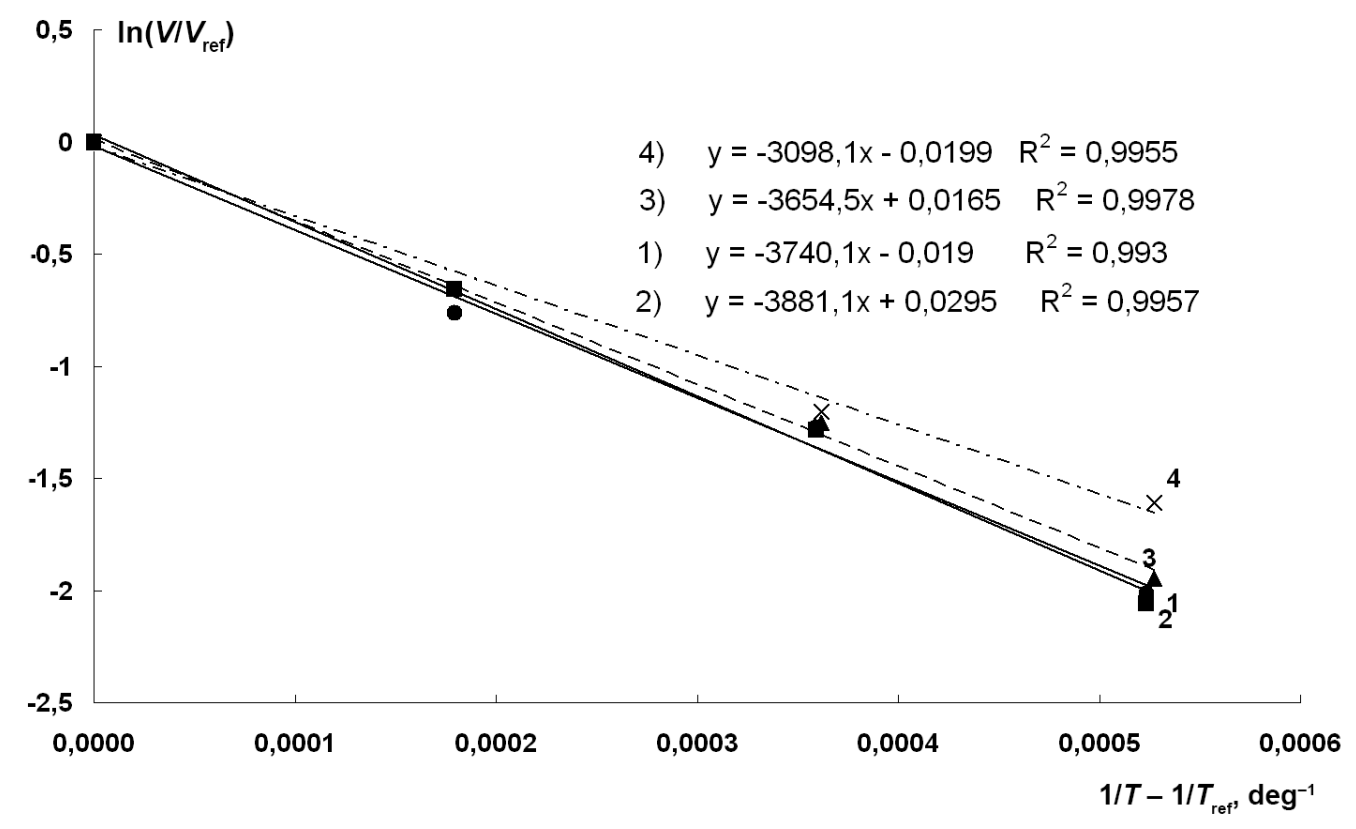

Figure 3. Arrhenius plots of the crack growth rate in solutions: $\mathrm{CB}(1), \mathrm{CB}+\mathrm{Na}_{2} \mathrm{~S}(2), \mathrm{CB}+\mathrm{IFKhAN}-$ 29-3 (3), and $\mathrm{CB}+\mathrm{Na}_{2} \mathrm{~S}+$ IFKhAN-29-3 (4). 
It is of interest to compare the $E_{\mathrm{a}}$ values (Table 1) with the activation energy of corrosion of carbon steels and low-alloyed steels in acidic electrolytes. In fact, the following corrosion activation energies were obtained for carbon steel in $1 \mathrm{M} \mathrm{HCl}$ : 27.9 [21], 40.37 [22], and $55.75 \mathrm{~kJ} / \mathrm{mol}$ [23]. A study of the corrosion of low-alloyed pipe steels gave $59.73 \mathrm{~kJ} / \mathrm{mol}$ for X60 steel in $1 \mathrm{M} \mathrm{H}_{2} \mathrm{SO}_{4}$ [24] and $36.76 \mathrm{~kJ} / \mathrm{mol}$ for X70 steel in 0.5 $\mathrm{M} \mathrm{HCl}$ [25]. Thus, the measured $E_{\mathrm{a}}$ values in citrate buffer fit in the range of corrosion activation energies of pipe steel in acidic solutions.

It should be emphasized that the measured activation energies of crack growth (Table 1) are formal values since the SCC process (as any other corrosion process) includes a few reactions. However, the $E_{\mathrm{a}}$ values exceed $20 \mathrm{~kJ} / \mathrm{mol}$ (Table 1); this indicates that a surface reaction is the stage determining the crack growth [26]. It is believed that it is the formation of an activated complex on the metal surface upon the metal ionization [2125 ], and this stage generally determines the rate of the overall anodic dissolution of iron or steels in acidic electrolytes.

As noted above, the diffusion of hydrogen atoms in the metal towards the crack tip may be yet another process controlling the SCC of pipe steels. The activation energy of hydrogen diffusion in the lattice of pure iron depends on a number of factors, in particular, the metal structure and the temperature range, but it is below $10 \mathrm{~kJ} / \mathrm{mol}$. For example, on well annealed iron in the range of $T=233-353 \mathrm{~K}$, the most probable $E_{\mathrm{a}}$ value is $5.69 \mathrm{~kJ} / \mathrm{mol}$ [27]. Data are available that the activation energies of hydrogen diffusion in pipe steels are higher, e.g., $15.5 \mathrm{~kJ} / \mathrm{mol}$ [28]. However, the hydrogen diffusion coefficient $(D)$ reported in [28] is by two orders of magnitude lower than that generally accepted for the steady-state diffusion of hydrogen in the metal lattice [27]. Apparently, the $E_{\text {a }}$ value was calculated from non-steady state $D$ values. As a result, the temperature dependence of $D$ may be expressed more distinctly, since the activation energy of population of hydrogen "traps" is several dozens $\mathrm{kJ} / \mathrm{mol}$ [29], and hence the non-steady-state hydrogen diffusion slows down upon a temperature decrease more strongly than under steady-state conditions. In any case, the activation energy of hydrogen diffusion in the metal is considerably lower than the $E_{\mathrm{a}}$ values corresponding to the crack growth process in weakly acidic citrate buffer (Table 1). Thus, the $E_{\mathrm{a}}$ values obtained confirm that the corrosion crack growth is controlled by the anodic reaction of pipe steel dissolution rather than by the hydrogen diffusion in the metal.

Addition of the SCC inhibitor to the CB solution changes the $E_{\mathrm{a}}$ value insignificantly (Table 1), and it appears that this effect can be neglected. However, the activation energy of crack growth in inhibited sulfide-containing solution (CB $+\mathrm{Na}_{2} \mathrm{~S}+$ IFKhAN-29-3) decreases considerably; hence, the efficiency of inhibitory protection increases with an increase in the temperature. This effect may be due to the formation (or strengthening) of chemical bonds between the organic molecules and the metal surface, i.e., an increase in the inhibitor chemisorption with an increase in temperature [30, 31]. Yet another explanation may lie in the acceleration of the inhibitor absorption on the freshly formed 
metal surface at the tip of a growing crack. In both cases, the decrease in the formal activation energy of crack growth should be due to an increase in the degree of coverage of the metal surface by the inhibitor.

\section{Conclusions}

1. The stress corrosion cracking of X70 pipe steel in weakly acidic buffer electrolyte $(\mathrm{pH}$ $5.5)$ becomes faster with an increase in the temperature. The activation energies of crack growth in the sulfide-containing and sulfide-free solutions are nearly the same and amount to 32.3 and $31.1 \mathrm{~kJ} / \mathrm{mol}$, respectively. These values are within the range of corrosion activation energies of carbon and low-alloyed steels in acids and intergranular SCC in carbonate-bicarbonate media. This confirms that local metal dissolution is the governing mechanism of pipe steel SCC in the weakly acidic electrolyte.

2. The IFKhAN-29-3 organic corrosion inhibitor hinders the SCC of pipe steel in the temperature range of $11-61^{\circ} \mathrm{C}$ and its inhibitive effect increases with an increase in the temperature. The formal activation energy of crack growth in the sulfide-containing solution decreases to $25.7 \mathrm{~kJ} / \mathrm{mol}$ in the presence of the inhibitor, which should be due to an increase in the degree of coverage of the metal surface with the inhibitor with an increase in the temperature.

\section{Acknowledgements}

This study was financially supported by the Russian Foundation for Basic Research (grant no. 16-08-00445a).

\section{References}

1. A.I. Malkin, A.I. Marshakov and A.B. Arabei, Korroz.: mater., zashch., 2009, no. 10, 1 (in Russian).

2. A.I. Malkin, A.I. Marshakov, V.E. Ignatenko and A.B. Arabei, Korroz.: mater., zashch., 2010, no. 2, 1 (in Russian).

3. Public Inquiry Concerning Stress Corrosion Crackingon Canadian Oil and Gas Pipeline Steels, Report of NEB, MH-2-95, 1996, 147 pp.

4. A.B. Arabei and Z. Knoshinski, Stress corrosion cracking of main gaslines, Atlas, Moscow, Nauka, 2006, 106 pp. (in Russian).

5. T.K. Sergeeva, E.P. Turkovskaya, N.P. Mikhailov and A.I. Chistyakov, The state of the stress corrosion problem in the CIS countries and abroad, Information overview, Moscow, IRTs Gazprom, 1998, p. 98 (in Russian).

6. M. Baker, Department of Transportation. Office of Pipeline Safety. OPS TTO8 Integrity Management Program. Stress corrosion cracking study, Final report, 2005.

7. Y.F. Cheng, Stress Corrosion Cracking of Pipelines, John Wiley \& Sons, Inc., Hoboken, New Jersey, 2013, 257 pp. 
8. R.N. Parkins and S. Zhou, Corros. Sci., 1997, 39, 159.

9. R.N. Parkins, W.K. Blanchard and B.S. Delanty, Corrosion, 1994, 50, 394.

10. S.L. Asher, B.N. Leis, J.A. Colwell and P.M. Singh, Corrosion, 2007, 63, no. 10, 932.

11. J.A. Beavers and K.C. Garrity, $100 \mathrm{mV}$ polarization criterion and external SCC of underground pipelines, Corrosion 2001, Paper 01592.

12. A. Contreras, M. Salazar, A. Albiter, R. Galván and O. Vega, Assessment of Stress Corrosion Cracking on Pipeline Steels Weldments Used in the Petroleum Industry by Slow Strain Rate Tests, in: Arc Welding, Ed. W. Sudnik, ISBN 978-953-307-642-3, Published: December 16, 2011 under CC BY 3.0 license, p. 144.

13. NACE Test Method TM 0177 "Laboratory Testing of Materials for Resistance to Specific Forms of Environmental Cracking in $\mathrm{H}_{2} \mathrm{~S}$ Environments", NACE, Houston TX, USA, 2005.

14. V.E. Ignatenko, A.I. Marshakov, V.A. Marichev, Yu.N. Mikhailovsky and N.A. Petrov, Zashch. met., 2000, 36, no. 2, 132.

15. A.B. Arabei, R.I. Bogdanov, V.E. Ignatenko, T.A. Nenasheva and A.I. Marshakov, Fizikokhimiya poverkhnosti i zashchita materialov, 2011, 47, no. 2, 1 (in Russian).

16. R.I. Bogdanov, A.I. Marshakov and V.E. Ignatenko, Korroz.: mater., zashch., 2011, no. 11, 30 (in Russian).

17. A.I. Marshakov, V.E. Ignatenko, R.I. Bogdanov and A.B. Arabey, Corros. Sci., 2014, 83, 209.

18. V.E. Ignatenko, Yu.I. Kuznetsov, A.B. Arabei, R.V. Igoshin, R.I. Bogdanov and A.I. Marshakov, Korroz.: mater., zashch., 2011, no. 9, 16 (in Russian).

19. V.E. Ignatenko, Vo Tien, A.I. Marshakov, Yu.I. Kuznetsov, A.V. Muradov and I.V. Ryakhovskikh, Korroz.: mater., zashch., 2016, no. 11, 27 (in Russian).

20. B.T. Lu, Eng. Fract. Mech., 2014, 131, 296.

21. M.A. Quraishi, K.R. Ansari, D.K. Yadav and E.E. Ebenso, Int. J. Electrochem. Sci., 2012, 7, 12301.

22. R.S.A. Hameed, Port. Electrochim. Acta, 2011, 29, no. 4, 273.

23. R. Salghi, Y. Ramli, B. Hammouti, S.S. Al-Deyab, E.M. Essassi and H. Oudda, Int. J. Electrochem. Sci., 2012, 7, 8958.

24. S.A. Umoren, I.B. Obot, A. Madhankumar and Z.M. Gasem, Carbohyd. Polym., 2015, 124, 280.

25. El-S.M. Sherif and A.H. Seikh, Int. J. Electrochem. Sci., 2015, 10, 209.

26. L. Herrag, B. Hammouti, S. Elkadiri, A. Aouniti, C. Jama, H. Vezin and F. Bentiss, Corros. Sci., 2010, 52, 3042.

27. K. Kiuchi and R.B. McLellan, Acta metall., 1983, 31, 961.

28. P. Fassina, M.F. Brunella, L. Lazzari, G. Re, L. Vergani and A. Sciuccati, Eng. Fract. Mech., 2013, 103, 10.

29. P.C. Rivera, V.P. Ramunni and P. Bruzzoni, Corros. Sci., 2012, 54, 106. 
30. E.E. Oguzie, V.O. Njoku, C.K. Enenebeaku, C.O. Akalezi and C. Obi, Corros. Sci., $2008, \mathbf{5 0}$, no. 12,3480 .

31. A. Popova, E. Sokolova, S. Raicheva and M. Christov, Corros. Sci., 2003, 45, no. 1, 33. 